\title{
THE IMPACT OF WORK LIFE BALANCE ON JOB SATISFACTION OF MANAGERIAL LEVEL EMPLOYEES OF PEOPLE'S BANK, (HEAD OFFICE), SRI LANKA
}

\author{
Mohamed Uwais Fathima Rifadha
}

\author{
Y.M.S.W.V. Sangarandeniya \\ Department of Human Resource Management \\ Faculty of Commerce and Management Studies \\ University of Kelaniya.
}

\begin{abstract}
Many researches were conducted to identify the Impact of Work Life Balance on Job Satisfaction of the employees in many organizations. However, conducting a research to explore the Impact of Work Life Balance on Job Satisfaction among the bankers, especially for managerial level of state bank is very rare. The researcher has decided to overcome this issue and therefore, the main purpose of this study is to identify the Impact of Work Life Balance on Job Satisfaction of the managerial level employees of People's Bank,(Head office) Sri Lanka. The researcher started the study by going through relevant literatures by many ways. Stratified random sampling method was followed. The final results shows, that there is a significant positive Impact of Work Life Balance on Job Satisfaction of managerial level employees. And Level of Work Life Balance and Job Satisfaction is low among the managerial level employees. However female employees are satisfied higher than male managers.
\end{abstract}

Keywords : Work Life Balance (WLB) and Job Satisfaction (JS)

\section{Introduction}

Effective utilization of human resource is one of the important factors for any organization. Well managed human resource, is crucial for organizational success. With the opening up the new economy and globalization of trade and commerce, the competition has increased diversely. In the era of organizational restructuring it is important for the organizations to take care of their efficient employees. The aim of take caring the employees is ultimately to provide them the satisfaction which will increase their job performance and ultimately will drive the organization to achieve competitive advantage over their competitors. Numerous discussions and arguments have been carried out on the issues of Work Life Balance and employee satisfaction.

There are many factors affecting the employee satisfaction at work, among those concern for Work Life Balance is increasing. 
According to Opatha (2010), work life means "life that is related to a person's employment". And what happened in the work life has significant impact on their family as well as on their personnel life and vice versa. There has been increasing interest in the conflict between family and work domains in the recent years.

Job Satisfaction is a mental feeling of favorableness which an individual has on his/ her job. To the employees, job satisfaction brings positive job related attitudes.A satisfied employee is more likely to be highly productive, creative, flexible, committed and loyal to the organization. (Ajmir, 2001). According to Opatha (2009),

Creating Work Life Balance will lead to Job Satisfaction. According to Korpunen and Napravnikova (2007) Work Life Balance and Job Satisfaction are important factors among organizations relevant to private sector and public sector as well.

The bankers, especially who works as managers feel very stress and pressures due to the vast changes made recently. Although numerous studies have been conducted on Work Life Balance and Job Satisfaction all over the world, only a limited amount of researches have been carried out in Sri Lankan context on the same topic, and especially in the context of banking sector. Therefore this research focuses on identifying The Impact of Work Life Balance on Job satisfaction of managers of Peoples Bank,(Head Office) Srilanka.

\section{Literature Review}

\section{Work Life Balance (WLB)}

The research studies providing theoretical support for the current study are as follows.
Various researchers defined Work Life Balance differently.

According to Professor Opatha (2001) the balance is, "the steadiness, importance or strength that we have between two things. Consequently, Work Life Balance is a good balance between work life and personal/family life of an individual. Balance between work life and the family life is defined as the degree to which you fulfill demands coming from your employment and your family. If you fulfill the respective demands in the way that generates satisfaction, it is possible to say that you have a right balance between work and family.

By the end of 1980, WLB was considered as an issue for not only women, but also for men (Bird, 2006). Similarly, Lewis (2003), cited from Lewis et al. (2000), stated that the discussion on work life is more gender neutral and is a concern of both men and women who try to balance between family responsibilities, workplace and leisure.

As per Bird, WLB cannot be defined as equal balance of time for both work life and individual life by scheduling equal number of hours as nobody can do it in the practical life. The key assumptions of the concept of work life balance are that both work and life are separate and that balance between those two spheres is needed.

Work Life Balance policies and practices can bring clear benefits to their business (Narendernath, 2007; The Business Case, 2001). . All in all Work Life Balance is said to also improve the quality of life of employees in that employees who experience WLB are fully engaged in both roles, not allowing urgencies in either their work or family domain to affect 
their performance in either of these roles chronically (Ashlesha Singh, 2013).

Therefore, we can conclude that Work Life Balance is "the degree to which an individual can fulfill the demand coming from his/ her employment and demands coming from outside employment to the extent that makes them happy."

\section{Job Satisfaction}

Understanding of the meaning of the Job Satisfaction is very much important for this study, since it is the Dependant variable. The researcher has referred some definitions quoted by expert writers with respect to the same.

Kamal and Sengupta (2008) defined the term satisfaction as a simple feeling/state accompanying the attainment by an impulse of his/her objectives and job satisfaction therefore, refers to ones view of favorableness of his/ her work. According to Opatha (2009), Job satisfaction means, "the degree of enjoyment an employee feels towards his job being performed".

The most popular is the one by Loche from 1976, which describes Job Satisfaction, is a pleasurable or positive emotional reaction to a person's job experiences (Locke, 1976, as cited in Milkovich \& Boudreau, 1997). Job satisfaction can be defined as the collection of feelings and beliefs about a current job (Jones, George, \& Hill, 2000), as a positive attitude that is believed leads to high performance (Daft \& Marcic, 2001), or as a reflection of an employee's feelings about various aspects of work (Stone, 2005).

Organizations face new challenges and gets new opportunities as well due to globalization, growing economy and development of information technology. Well committed employees due to the higher level of satisfaction are the most valuable assets of any nation's economy as they act as competitive advantage in the long term (Khalid \& Irshad, 2010).

In general, "Job Satisfaction is a mental feeling of favorableness which an individual has about his Job and the organizations in which they perform these jobs". Overall job satisfaction is determined by the difference between all those things a person feels he should receive from his job and all those things he actually does receive.

\section{Relationship between Work Life Balance and Job Satisfaction}

For the current study the term employee Job satisfaction can be defined as an employee is said to be satisfied from his/her work when he/she feels comfort while working in the organization. Whereas Work Life Balance means that an employee is comfortably accomplishing his/her work and non - work responsibilities. Emerging trends in work force diversity, organizational restructuring and addition of women in the workforce enhanced the demand for the work life balance practices to be adopted by the organizations.

Nadeem and Abbas (2009) examined a relationship of Work Life Conflict and Job Satisfaction and revealed a negative relationship of the variables and suggested that the supportive management can be a medicine to minimize the conflict and enhance satisfaction among employees. In another study Malik, Saif, Gomez, Khan and Hussain (2010) 
reported a positive and significant relationship of job satisfaction and work family balance.

According to Anwer and Ikram (2009), satisfaction of the job is a part of life satisfaction that can only happen if employees can create a balance between their work and family life. Further they revealed that the employees who have high work life balance are more satisfied with their jobs when compared to the employees who have low work life balance.

Therefore, we could state that the empirical researches suggest that, there is a relationship between work life balance and employee satisfaction.

\section{Statement of the problem}

Banking sector is considered to be a very competitive, compared to other sectors. Since there are many competitors available in the industry and rivalry among them are very high Normally Banker's job is considered to be highly stress full and the organization should take necessary steps to look after their employees in a manner they are satisfied, and also there are only few researchers has identified the Work Life Balance practices especially on State sector banks, therefore this research is Focused on identifying or investigating the Impact of Work Life Balance on the Job satisfaction of Managerial level employees of Peoples' Bank.

\section{Research objectives}

Major objective of conducting this research is to, Identify the Impact of Work Life Balance on the Job Satisfaction of Managerial level employees of People's bank, (Head office) Srilanka.

In order to reach the above said major objective, the following sub objectives are specifically considered.

$>$ To determine the level of Work Life Balance of Managers

To determine the level of Job Satisfaction of Managers Pendentis

To Asses linkage between the Work Life Balance and Job satisfaction

\section{The Research Design}

\section{Theoretical Frame work and Operationalization}

The purpose of the study is to identify the impact of Work Life Balance on the job satisfaction on the managerial level employees. Previous studies on Work Life Balance Job satisfaction shows there is a strong relationship between these two concepts. (Kumari, 2012; Yadav \& Dabhade, 2013). Therefore Work Life Balance and Job Satisfaction is highly related to another. Independent Variable is Work Life Balance. It can be categorized into following three dimensions as follows,

1. Personal factors

2. Job related factors

3. Organizational factors:.( Yadav and Dabhade (2013)

Job Satisfaction is the dependent variable in this study. It can be categorized into following two dimensions as follows,

1. Intrinsic Job Satisfaction:

2. Extrinsic job satisfaction: (Hirschfield, 2000)

Based on that, the conceptual framework for the study is shown in the Figure 1. 
Figure 1 : Conceptual Frame work

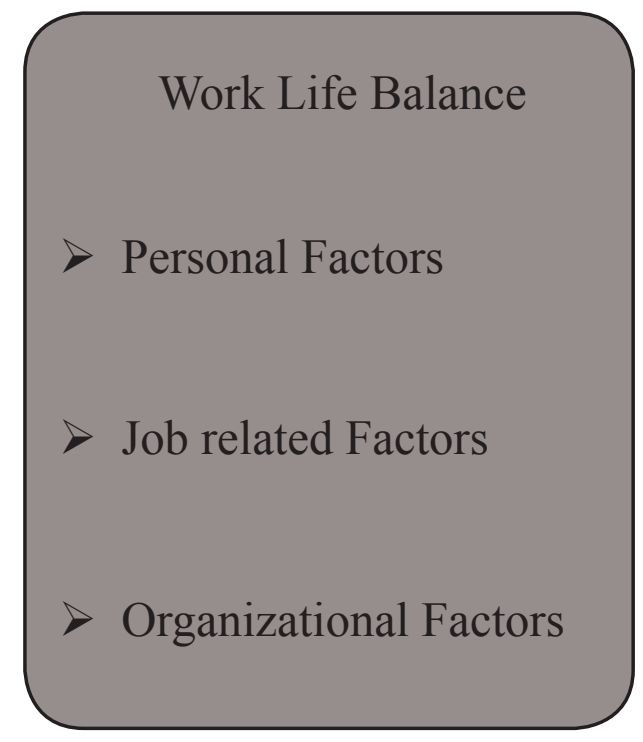

\section{Hypotheses development}

Based on the researcher's observations on the working patterns, employee behaviors the turnover rates, and the other factors which are specified in the problem identification stage, as well as after the discussions made with the few managers in the bank, the researcher assumed the level of Work Life Balance and the Job satisfaction is at the lower level.

Hence the following hypotheses were suggested to be tested:

\section{$\mathrm{H}_{1}$ : Work Life Balance of managerial level} employees of peoples' Bank is, at a Lower Level.

\section{$\mathrm{H}_{\mathbf{1}}$ : Work Life Balance of managerial level} employees of peoples' Bank is, at a Lower Level.

According to Anwar \& Ikram (2009), job satisfaction is a part of life satisfaction that can only happen if employees can create a balance between their work and family life. According

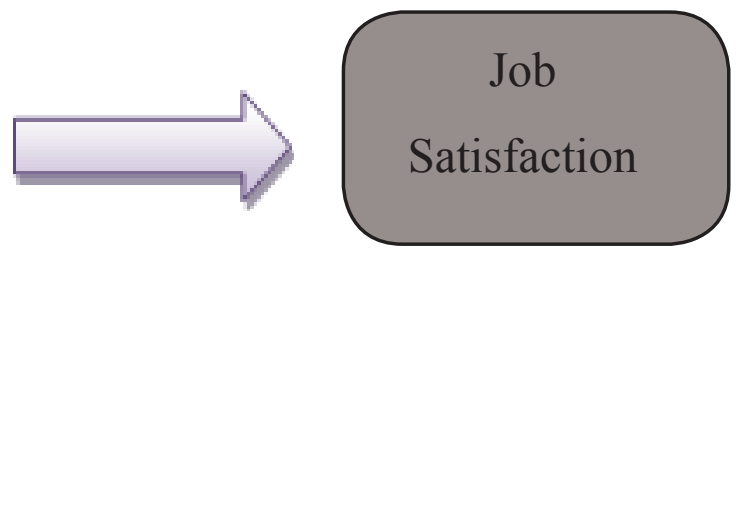

to them, employees who are having more work life balance are more satisfied with their jobs when compared to the employees who have low work life balance. Satisfaction with work life balance is the strongest predictor of job satisfaction and lack of work life balance results in a reduction in job satisfaction (Saltzstein and Ting, 2001).

Hence the following hypothesis was suggested to be tested:

\section{$\mathrm{H}_{3}$ : There is a significant Positive impact} of Work Life Balance on Job Satisfaction of managerial level employees of People's

\section{Bank.}

\section{Data collection}

The population for the study is Managerial level employees of People's Bank, who are working head office. There are three Grades are available under the grade of managers. According to the information received from the HR department of People's bank, the following population details could be identified. 


\begin{tabular}{|llr} 
Assistant Managers ( 3III ) & - & 75 \\
Deputy Managers ( 3II ) & - & 149 \\
Managers ( 3I ) & - & 96 \\
Total & $=$ & $\underline{\underline{320}}$
\end{tabular}

For selecting the sample researcher used stratified sampling method. And data was collected from 100 managers .This sampling method reflects more accurately the population by more proportional representation.

Primarily the data collection was carried out by distributing the hard copy of the questionnaires to the sample

The questionnaire consists of 30 statements.

- Part 1 - Personal data about the employees. (06 Questions)

- Part 2 - Questions regarding Work Life Balance factor and Job Satisfaction. (30 Questions)

The questionnaire consist with Five point likert scale type questions ranking from, 1 = 'strongly agree' (5 marks) to $5=$ 'strongly disagree' (1 mark) to measure variables.

In addition to that researcher has reviewed Financial statements, Annual reports, Further, some previous research papers which have similarities with this study have also been gone through by the researcher.

\section{Data Analysis methodology}

SPSS 17.0 version was used to analyze the data. The questions and responses were coded and entered into SPSS to analysis.. By using SPSS the researcher has measured the correlation as well as conducted regression analysis. The content validity of the instrument was ensured by the conceptualization and operationalization of the variables based on literature.

According to De Vellis, 2003, the Julie Pallant (SPSS Survival manual, 2011) explains that Cronbach's Coefficient Alpha of a scale should be more than 0.7 and values which are above 0.8 are preferable In this case, the value for the Work life balance and Job satisfaction are shown in the Table 4.7 above as 0.895 and 0.890 respectively which can be considered as a good inter-item reliability.

\section{Results and Discussion}

The overall results shows that, most of the respondents feel low (60\%) and moderate level $(36 \%)$ of Balance between Work and Personal Life. only $3.5 \%$ of them feel high Work Life Balance.

Majority of the respondents have low Job Satisfaction and Moderate Job satisfaction. However they have some satisfied with the Job Extrinsic factors when comparing with Job Intrinsic satisfaction factors. Majority $(65.1 \%)$ of them are male managers. Even though both the male and female in overall, experience lower level Work Life Balance and Job Satisfaction, level of the Job Satisfaction of male managers is lower than female managers of the bank. Therefore, female managers have a balance between their work and personal/ family life than the male managers.

Also most of the $75 \%$ respondents have highly disagree with the Job related factors in achieving Work Life Balance comparing to other two dimensions of Work Life Balance. ( Personal and Organizational factors). 
According to the sample results, most of the respondents are more than 50 years. They are represented by 3I (manager) and 3II (deputy managers) who are having more working experience in Peoples Bank 25- more than 30 years. If we take the Job Grade composition and Work Life Balance, most of the (76.9\%) 3 I managers have low Work Life Balance and (73\%) Low Job Satisfaction. Most of the 3 II managers also have low level of Work life
Balance and Low Job Satisfaction. However most of the 3 III managers are $(75 \%)$ moderately satisfied and $(70 \%)$ have moderate Work Life Balance. And $15 \%$ of them have high Work Life Balance and are highly satisfied with the job. It is s because 3I managers are seniors and they high responsibilities big targets to be achieved. As well as they have to spend more time at work.

Hence Hypothesis 1 and 2 is accepted

Table. 1: Correlation between Work Life Balance and Job Satisfaction

\begin{tabular}{|c|c|c|c|}
\hline \multicolumn{2}{|l|}{ Correlation analysis } & Work Life Balance Scale & Job Satisfaction Scale \\
\hline \multirow[t]{3}{*}{ Work Life Balance } & Pearson Correlation & 1 & $.792 * *$ \\
\hline & Sig. (1-tailed) & & .000 \\
\hline & $\mathrm{N}$ & 86 & 86 \\
\hline \multirow[t]{3}{*}{ Job Satisfaction } & Pearson Correlation & $.792 * *$ & 1 \\
\hline & Sig. (1-tailed) & .000 & \\
\hline & $\mathrm{N}$ & 86 & 86 \\
\hline
\end{tabular}

**. Correlation is significant at the 0.01 level (1-tailed).

Table 2: Regression Analysis

\begin{tabular}{|l|l|l|l|l|}
\hline Model & $\mathrm{R}$ & R square & $\begin{array}{l}\text { Adjusted R } \\
\text { Square }\end{array}$ & $\begin{array}{l}\text { Std. Error of the } \\
\text { Estimate }\end{array}$ \\
\hline 1 & $.792 * *$ & .628 & .623 & .37332 \\
\hline
\end{tabular}

a. Predictors: (Constant), Work Life Balance

Table 3: Coefficient of the Variables

\begin{tabular}{|l|c|c|c|c|c|}
\hline \multirow{2}{*}{ Model } & \multicolumn{2}{|l|}{ Unstandardized Coefficients } & \multicolumn{2}{|l|}{$\begin{array}{l}\text { Standardized } \\
\text { Coefficients }\end{array}$} & \\
\cline { 2 - 4 } & $\mathrm{B}$ & Std. Error & Beta & $\mathrm{t}$ & Sig. \\
\hline (Constant) & .642 & .159 & & 4.031 & .000 \\
\hline $\begin{array}{l}\text { Work Life } \\
\text { Balance }\end{array}$ & .748 & .063 & .792 & 11.903 & .000 \\
\hline
\end{tabular}

a. Dependent Variable: Job Satisfaction 
In order to test the relationship between the two variables, the Pearson Product-Moment Correlation technique was used. It is evident from the above Table (1) that the p-value is lower than the significant level (0.01) further the correlation value of 0.792 (positive) insists that, there is a strong positive correlation between the Work Life Balance and Job Satisfaction.

According to the regression analysis $\mathrm{R}^{2}$ value is .628 (Table 2), which means the Independent Variable in this study Work Life Balance has $62.8 \%$ impact on the Dependent Variable (Job Satisfaction).

The results show that there is a strong positive relationship between the Work Life balance and the Job Satisfaction of them. And also there is a significant Impact of Work Life Balance on the Job Satisfaction of them.

Hence Hypothesis 3 is also accepted.

In addition to above facts, following finding can also be revealed,

- The results show that Work Life Balance is an important determinant of intrinsic aspects of Job Satisfaction.

- Management and employee both are responsible for having Work life Balance.

- If the employees are given freedom to choose their work schedules; quality and productivity of work increases. Because if this opportunity given to the employee it will bring the responsibility for finishing work within specified deadline.

- $\quad$ High quality of Work Life Balance will improve the Job satisfaction and vice versa.
The major finding which was acquired from this study is the strong relationship between Work Life Balance and Job satisfaction. And the Impact of Work Life balance on the Job Satisfaction is significant. The previous research conducted by Malik (2010), Saltzstein and Ting (2001), and Yadav and Dabhade (2013) were supported to this finding. Further, Ikram and Anwar (2009) also confirmed by their research that there is a relationship between Work Life balance and job satisfaction.

In addition to that, Kamal and Sengupta (2008) findings revealed that, there is a low level of Job Satisfaction among the bankers .Another important finding of the study is that the level of Job Satisfaction and Work Life Balance of the female managers are higher than the male manager which was agreed with findings of Malik (2010).Therefore, the finding of the study has similarities with previous studies.

\section{Conclusion}

The banking sector which comes under service sector completely depends on customers and therefore, they treat their customers as kings. And also level of competition in the banking sector is very high. In order to retain the customers, the banks should provide a quality service Therefore, the employees especially managers, should be motivated by the management to get positive involvement to achieve bank's target.

It could be concluded, that there is a significant positive impact of Work Life Balance on Job Satisfaction of the managerial level employees of People's Bank. And high quality of Work 
Life Balance will improve the Job satisfaction and vice versa. Results of the study further Indicate that the Work Life Balance and the Job Satisfaction of managerial level employees of People's Bank are at lower level.

Flexible Work Life Balance initiatives should be designed by the management to help the employees to balance their Work and Personal Life. As well they should increase the intrinsic aspects of Job Satisfaction which is how people feel about the nature of the job tasks themselves and on the other hand extrinsic Job Satisfaction is how people feel about aspects of the work situation that are external to the job tasks or the work itself. If employees feel that that they are able to balance their Work and Life they will be highly satisfied with their job and it will lead to high productivity and High profitability of the bank. Hence, "Work Life Balance is not a problem to be solved but an ongoing issue to be managed".

\section{References}

Abbas, Q., \& Nadeem, M.S. (2009). The impact of work life conflict on job satisfactions of employees in Pakistan. International Journal of Business and Management, 4(5), 63-83.

Abou-Zaki, B., \& Crossman, A. (2003). Job satisfaction and employee performance of Lebanese banking staff. Journal of Managerial Psychology, 18 (4), 368-376.

Yadav, R. K., \& Dabhade, N. (2013). Work life balance among the working women in public sector banks-a case study of state bank of India.
Melanie, a. (2012). An empirical investigation into the impact of work-life balance practices on employees and employers.

Abbot, J., Ceiri, H. D., Holmes, B., \& Pettit, T. (2002). Work life balance strategies: Progress in Australian organizations. Faculty of business studies and economics, Monashuniversity, Australia.

Hulya, H., Fiona, N., \& Miranda, M. (2011). The third work-life balance employee survey: Main findings (revised edition with corrected figures).

Dr. Muhammad, I. M., \& Muhammed, I.S (2011). Employee work satisfaction and work - life balance: A Pakistani perspective.

Ahmad, M., Gomez, S.F., Malik, M.I., \& Saif, M.I. (2010). Examining the relationship of work life balance, job satisfaction and turnover in Pakistan. Journal of Sustainable Development, 2(1), 27-33.

Ahmad, M., Malik, M.I., \& Saleem, F. (2010). Work-life balance and job satisfaction among doctors in Pakistan. South Asian Journal of Management, 17(2), 112-123.

Maria, T., Anna-Maria, M., \& Dimitris, P. (2008). Extrinsic job satisfaction of employees, regarding their intention to leave work position. a survey in small and medium enterprises.

Sakthivel, R., Kamalanabhan, B., \& Selvarani, A. (2011). Work / life balance reflections on employee satisfaction. Serbian Journal of Management 6 (1) (2011) 85 - 96. 
Simonetta, M., \& Michelle, H. (2004). Worklife balance an audit of staff experience at oxford brookes university.ISBN 1873576 706.

Farah, M. (2012). Work life balance and job satisfaction among faculty at Iowa state university.

Sinha, A. N. (1988). Job satisfaction a study of bank employees. New Delhi-110002, India: Common wealth publishers.

Antvor, H.G., Eskildsen, J., \& Kristensen, K. (2010). The Relationship between Job Satisfaction and national culture. The TQM Journal, 22(4), 369-378.

Anwar,M., \& Ikram, S.I(2009).Relationship between work life balance and job satisfaction among employees.

Asadullah, M.N., \& Fernandez, R.M.(2008). Work life balance practices and the gender gap in job satisfaction in the UK: Evidence from matched employer- employee data, Germany.

Aksu, A. A., \& Aktas, A. (2005). Job satisfaction of managers in tourism: Cases in the antalya region of turkey. Managerial auditing journal, 20(5), 478-488.

Bedeian,A.G., Ferris, G.R.,\& Kacmar, K.M.(1992). Age, tenure \& job satisfaction: A tale of two perspectives.

Beham, B., \& drobnic, Good job Good life?, working conditions and quality life in Europe, social indicator research, 2010, (99) 205-225
Bhatnagar,J., \& Shankar, T. (2010). Work life balance, employee engagement, emotional consonance/dissonance \& turnover intention. Indian Journal of Industrial relations, 46(1), 74-87.

Bird, J.(2006). Work life balance: Doing it right and avoiding the pitfalls. Employment relations today, 33(3), 1-9.

Doble, N., \& Supriya, M.Y. Gender differences in the perception of work-life balance. Management, 5(4), 331-342.

Eikhof, D.R., Haunschild, A. \& Warhurst, C. (2007). Introduction: What work? What life? What balance? Employee Relations, 29(4), 325-333.

Ferris, M., Hawkins, A.J., Hill, E.J., \& Weitzman, M. (2001). Finding an extra day a week: The positive influence of perceived job flexibility on work and family life balance. Family Relations, 50(1), 49-58.

Fishwick, S., \& Wickham, M. (2008). Presenting a "career-life balance" approach to the work-life balance issue. International Review of Business Research Papers, 4(5), 87-96.

Gerhart, B., Hollenbeck,J.R., Noe, R.A, \& Wright,P.M. (2007). Fundamentals of Human Resource Management. (2 ${ }^{\text {nd }} E d$.). New Delhi, India: McGrow-Hill.

Glinow, M.A.V. (2005). Organizational Behavior. ( $3^{\text {rd }}$ Ed.). New York, America: McGraw- Hill. 122.

Greenblatt, E. (2002).Work/Life Balance: Wisdom or whining, Organizational dynamics. 31(2), 177-193. 
Doherty, L., \& Murphy, F. (2011). The experience of work life balance for Irish senior managers. Equality diversity and inclusion: An international journal.30 (4), 252-277.

Greenhaus, J.H.,Collins, K.M, \& Shaw, J.D. (2003). The relation between work-family balance and quality of life. Journal of Vocational Behavior, 63, 510-531.

Guest,D., \& Sturges, J. (2004). Working to live or living to work? Work/life balance early in the career. Human Resource Management Journal, 14(4), 5-20.

Irshad, M.Z., \& Khalid, S. (2010). Job satisfaction among bank employees in Punjab, Pakistan: A comparative study. European Journal of Social Sciences, 17(4), 570-577.

Kamal, R., \& Sengupta, D. (2008-2009). A study of job satisfaction of bank officers. Prajnan, 37 (3), 229-245.

Lewis, S. (2003). The integration of paid work and the rest of life. Is post-industrial work the new leisure? Leisure Studies, 22, 343355 .

Morganson, major, Oborn, Verive, \& Heelan (2009), Journal of managerial psychology, $25,578-595$.
Mullins, L.J., (1999) Management and Organizational Behaviour, $5^{\text {th }}$ edition, Financial Times Management, London

Nancy Lockwood, R. (2003). Work life balance: Challenges and solutions, Quarterly report magazine

Opatha, H.D.N.P, (2010). Personal Quality, Department of Human Resources Management, USJP, Col., 8(1) 133-153

Opatha, H.D.N.P. (2009). Human Resources Management Personnel, 1 (1), 1

Robbibs, S.P. (2003). Organizational Behavior. ( $5^{\text {th }}$ ed.). USA: prentice- Hall.

Saltzstein, A.L.,Saltzstein, G.H., \& Ting, Y.(2001). Work-family balance and job satisfaction: The impact of family friendly policies on attitudes of federal government employees. Public Administration Review. 61(4), 463.

Vlems, E. (2004). Work-life balance.

Quesenberry, J. L., \& Trauth, E. M. (2004). The role of ubiquitous computing in maintaining work-life balance: Perspectives from women in the information technology workforce. 